\title{
Responses of bahiagrass to nitrogen and defoliation
}

\author{
MASAHIKO HIRATA AND WEMPIE PAKIDING
}

Authors are Professor, Division of Grassland Science, Faculty of Agriculture, Miyazaki University, Miyazaki 889-2192, Japan (Email: m.hirata@cc.miyazaki-u.ac.jp); and Lecturer, Faculty of Animal Husbandry, Hasanuddin University, Makassar 90245, Indonesia. At the time of the research, Pakiding was a Postgraduate Student, United Graduate School of Agricultural Sciences, Kagoshima University, Kagoshima 890-0065, Japan.

Abstract

Pensacola bahiagrass (Paspalum notatum Flügge) swards pretreated with fertilizer nitrogen rates of 0 and $66-99 \mathrm{~kg} \mathrm{~N} \mathrm{ha-1}^{-1}$ year-1 $^{-1}$ were exposed to repeated, severe defoliation (i.e., removal of all laminae) of every day (D1), every 2 days (D2), and every 4 days (D4). Responses of the grass were monitored in terms of tiller survival, lamina production and changes in the mass of the stubble-stolon-root system, in an effort to investigate the effects of nitrogen rate and defoliation frequency on defoliation tolerance, to examine differences in survival ability of tillers among tiller age cohorts, and to evaluate contribution of the stubblestolon-root system to defoliation tolerance. With the progress of defoliation treatments over 12 weeks, the swards degraded with decreasing tiller density, lamina production, and mass of stubble and stolons. Defoliation tolerance in terms of tiller survival was influenced only by defoliation frequency $(\mathrm{D} 1 \approx \mathrm{D} 2<\mathrm{D4})$, with no significant effect of nitrogen fertilizer rate. There were no differences in survival ability of tillers among age cohorts formed before the defoliation treatments, suggesting that all tillers in bahiagrass were able to share energy and nutrients in connecting stolons under severe defoliation. It was confirmed that stolons play a key role in defoliation tolerance in bahiagrass as the main storage organ supporting aboveground parts, whereas the contribution of roots seems nil.

Key Words: Paspalum notatum, defoliation tolerance, tiller survival, lamina production, stubble-stolon-root system

Persistence of grasslands and rangelands is crucial for sustainable agricultural production and/or conservation of the environment (e.g., soil and water), wildlife, and recreational resource. In a grassland community, persistence of grasses is dependent on the ability of plants to maintain a high tiller density and the ability of individual tiller to maintain leaves (laminae) as photosynthetic organs (Hirata and Pakiding 2001, Pakiding and Hirata 2001).

When exposed to continuous severe defoliation, tillers depend greatly on storage organs such as stubble, stolons, rhizomes, and roots for energy supply to maintain themselves and produce leaves. As energy storage in the supporting organs declines, tillers are thought to compete with each other for energy, resulting in earlier death of tillers with lower competitive ability (Zhang and Romo 1995, McKenzie 1997).

Bahiagrass (Paspalum notatum Flügge), a sod-forming, warmseason perennial, is widespread in the southern USA and Central

Pakiding thanks the Japanese Ministry of Education, Culture, Sports, Science and Technology for financial support during his study in Miyazaki, Japan.

Manuscript accepted 14. Dec. 02

\section{Resumen}

Praderas de "Bahiagrass" (Paspalum notatum Flügge) pretratatdas con dosis de fertilización nitrogenada de 0 y $66-99 \mathrm{~kg} \mathrm{~N}$ $h^{-1} a^{n} o^{-1}$ fueron expuestas a defoliación severa (i.e. remoción de toda la lámina) y repetida, cada día (D1), cada 2 días (D2) y cada 4 días (D4). La respuesta del zacate fue monitoreada en términos de sobrevivencia de hijuelos, producción de tejido laminar de la hoja y cambios en la biomasa del sistema rastrojo-estolónraíz, esto en un esfuerzo por investigar los efectos de la dosis de nitrógeno y la frecuencia de defoliación en la tolerancia a la defoliación, para examinar las diferencias en la habilidad para sobrevivir de los hijuelos entre generaciones de ellos y para evaluar la contribución del sistema rastrojo-estolón-raíz a la tolerancia al a defoliación. Al progresar los tratamientos de defoliación hasta 12 semanas, la pradera se degradó con la disminución de la densidad de hijuelos, la producción de lámina y la masa de estolones y rastrojo. La tolerancia a la defoliación en términos de sobrevivencia de hijuelos fue influenciada solo por la frecuencia de defoliación (D1 $\approx D 2<D 4)$ sin un efecto significativo de la dosis de fertilización. No hubo diferencias en la habilidad de sobrevivencia de los hijuelos entre generaciones de hijuelos formadas antes de los tratamientos de defoliación, sugiriendo que bajo condiciones de defoliación severa todos los hijuelos en "Bahiagrass" fueron capaces de compartir energía y nutrientes entre los estolones conectados. Se confirmó que los estolones juegan un papel clave en la tolerancia a la defoliación de "Bahiagrass" como el órgano principal de almacenamiento sosteniendo las partes aéreas mientras que la contribución de la raíz parece ser nula.

and South America (Skerman and Riveros 1989). It is also widely distributed in the low-altitude regions of southwestern Japan. This grass forms a highly persistent sward which tolerates severe defoliation (Beaty et al. 1970, 1977, Stanley et al. 1977, Hirata 1993a, 1993b, Hirata and Ueno 1993). Beaty et al. (1970) reported that bahiagrass performed well even under weekly cuttings at the soil surface level.

However, how bahiagrass behaves under extremely severe defoliation is not fully explored. Only by applying such a condition, we can determine the limit to which each mechanism behind the persistence of bahiagrass successfully works, and understand the overall ability of the grass to tolerate defoliation.

In this study, we imposed repeated, severe defoliation (i.e., removal of all laminae) of different frequencies on bahiagrass swards pretreated with different rates of nitrogen fertilizer, and monitored tiller survival, lamina production, and changes in the mass of the stubble-stolon-root system of bahiagrass. The aims of the study were to investigate the effects of nitrogen rate and defoliation frequency on defoliation tolerance in bahiagrass, to exam- 
ine differences in survival ability of tillers among tiller age cohorts, and to evaluate contribution of the stubble-stolon-root system of bahiagrass to defoliation tolerance.

\section{Materials and Methods}

\section{Study site and experimental plots and design}

The study was conducted on an established sward of bahiagrass at the Faculty of Agriculture, Miyazaki University, Japan (31 $\left.50^{\circ} \mathrm{N}, 131^{\circ} 24^{\prime} \mathrm{E}\right)$. The meteorological conditions during the study are shown in Fig. 1. In March 1998, 24 plots $(30 \times 30 \mathrm{~cm})$ were established in the sward. Each plot was isolated from the surrounding area by driving 4 iron plates ( $30 \times 30 \mathrm{~cm}$ in area and $3 \mathrm{~mm}$ thick) into the soil to a depth of about $26 \mathrm{~cm}$. The 24 plots were grouped into 3 blocks or replications with 8 plots each.

The experiment consisted of 2 stages, i.e., nitrogen treatments from April 1998 to July 2000 and defoliation treatments from August to October 2000. The first stage also included regular tagging of tillers to follow the fate (survival) of individual tiller age cohorts during defoliation treatments. Out of the 8 plots in each block, 2 plots were destructively sampled at the end of nitrogen treatments (beginning of defoliation treatments) to evaluate nitrogen effects on the stubble-stolon-root system. The experimental design at this first stage was an arrangement of 2 nitrogen fertilizer rates, with 3 replications in randomized blocks. Then, the remaining 6 plots in each block were used to evaluate sustained effects of nitrogen and impacts of defoliation on dynamics in tiller density, lamina production, and the stubblestolon-root system during defoliation treatments. The experimental design at this second stage was a factorial arrangement of 2 nitrogen fertilizer rates $\times 3$ defoliation frequencies, with 3 replications in randomized blocks.

\section{Nitrogen treatments}

Two nitrogen treatments $(0 \mathrm{~N}$ and $+\mathrm{N})$ were randomly allocated to the 8 plots in each block (4 plots for each treatment). The $+\mathrm{N}$ plots received 8 applications of 33 $\mathrm{kg} \mathrm{N} \mathrm{a}^{-1}$ over 3 years, i.e., in April, July, and September 1998 and 1999 and April and July $2000\left(99 \mathrm{~kg} \mathrm{~N} \mathrm{ha}^{-1}\right.$ annually in 1998 and 1999 but only $66 \mathrm{~kg} \mathrm{~N}^{-1} \mathrm{year}^{-1}$ in 2000). In addition to nitrogen, all plots (including $0 \mathrm{~N}$ plots) received $27 \mathrm{~kg} \mathrm{P_{2 } \mathrm { O } _ { 5 }}$ and $27 \mathrm{~kg} \mathrm{~K}_{2} \mathrm{O} \mathrm{ha}^{-1}$ at each application of
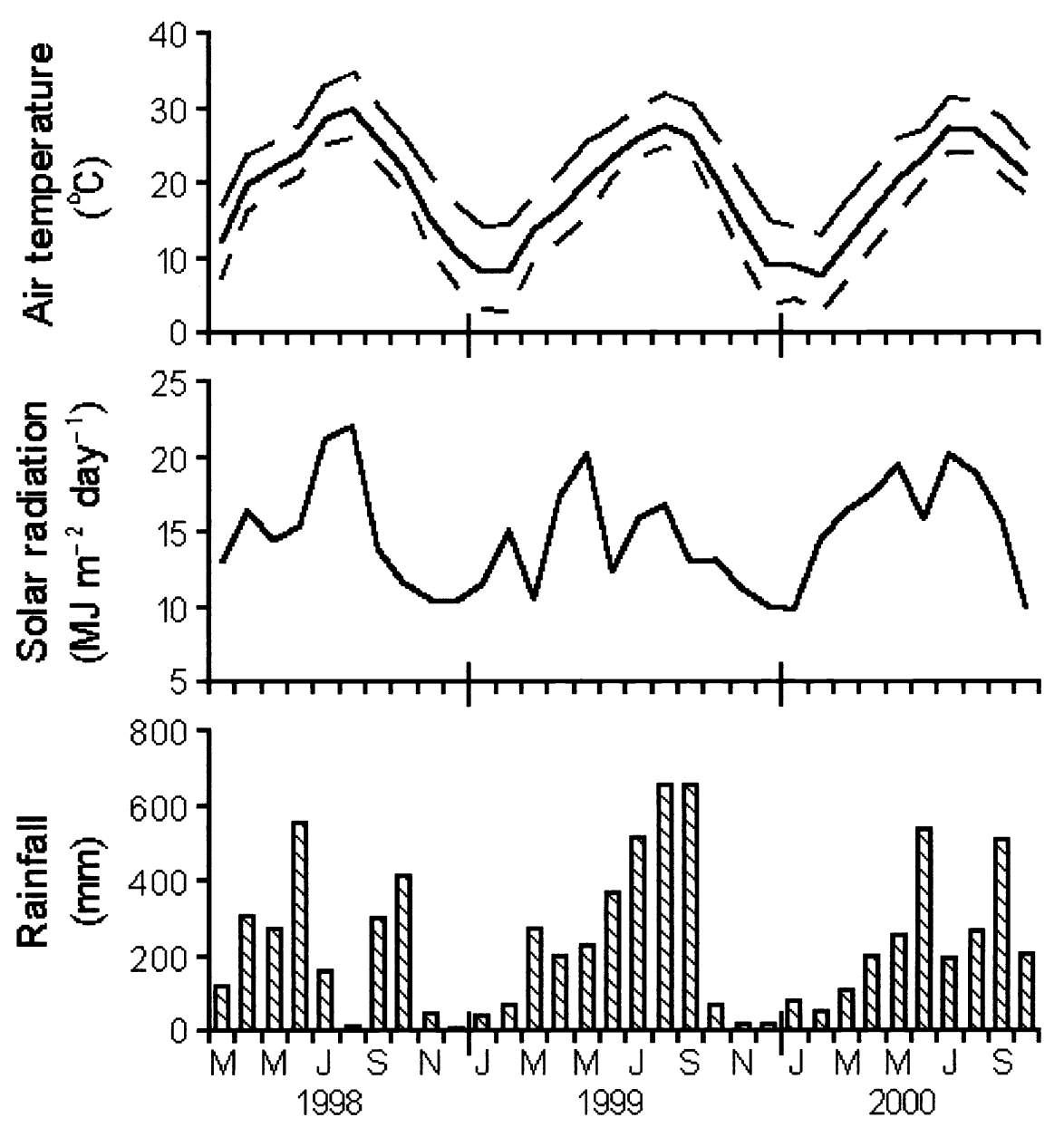

Time

Fig. 1. Monthly means of maximum (----), mean (-) and minimum (........) daily air temperatures, daily total short-wave solar radiation and monthly totals of rainfall at the Miyazaki Meteorological Station (about $10 \mathrm{~km}$ north of the study site) during the study.

$\mathrm{N}$. The sources of $\mathrm{N}, \mathrm{P}_{2} \mathrm{O}_{5}$, and $\mathrm{K}_{2} \mathrm{O}$ were ammonium sulfate, superphosphate, and potassium sulfate, respectively. During May to October of 1998 and 1999 and May to July of 2000 , all plots were cut monthly to a $2-\mathrm{cm}$ height above ground level.

\section{Tiller cohort identification}

Tillers were regularly tagged during the nitrogen treatments to follow the fate of individual tiller age cohorts during defoliation treatments. On the day of plot establishment (March 1998), a 20 x $20 \mathrm{~cm}$ permanent quadrat was established in the center of each plot. All live tillers within the quadrat were tagged with a wire ring (9 $\mathrm{mm}$ in diameter) with a colored bead at their base and grouped as the original tillers. This group consisted of tillers with various, unknown ages. Subsequent taggings were conducted at monthly inter- vals, and rings were removed from dead tillers at the same time. Beads of different colors were used to identify the times of tagging. Tillers were considered as dead when all parts were completely dried. The number of new tillers tagged and the number of rings removed from dead tillers were recorded, from which densities of tillers in different age cohorts at the commencement of defoliation treatments were obtained.

Tillers were classified into the following 11 age cohorts according to the period of their initiation: 1 . original tillers formed before March 1998, 2. spring 1998, 3. summer 1998, 4. autumn 1998, 5. winter 1998-1999, 6. spring 1999, 7. summer 1999 , 8. autumn 1999, 9. winter $1999-2000$, 10. spring 2000 , and 11 . summer 2000. Spring, summer, autumn, and winter corresponded to March-May, June-August, September-November, and December-February, respectively. 
Defoliation treatments and measurements of lamina production, tiller appearance and death

Defoliation treatments commenced in early August 2000 and continued during summer-autumn seasons. At the commencement, all 24 plots were defoliated to a $2-\mathrm{cm}$ height above ground level so that no laminae remained. Three defoliation treatments (D1, D2, and D4) were randomly allocated to 3 of the $0 \mathrm{~N}$ plots and 3 of the $+\mathrm{N}$ plots in each block; leaving a $0 \mathrm{~N}$ plot and $\mathrm{a}+\mathrm{N}$ plot in each block for sampling of the pre-treatment mass. D1, D2, and D4 plots were cut every day, every 2 days and every 4 days, respectively, to remove all regrown laminae until all tillers within the central quadrat of any 1 plot were dead. No undefoliated treatment was included because the study aimed to explore behavior of bahiagrass under extremely severe defoliation. Tiller death was judged as described earlier. No fertilizers were applied during the defoliation period.

Lamina yield was measured at each defoliation time, except for the initial cutting. Harvested laminae were oven-dried at $85^{\circ} \mathrm{C}$ for 72 hours for dry matter determination. Tiller appearance and death were monitored 5 days after the commencement of defoliation treatments and at 8-day intervals thereafter.

\section{Measurements of mass of stubble- stolon-root system}

Mass of the stubble-stolon-root system was measured at both the beginning and the end of defoliation treatments. The pretreatment mass was measured immediately after the initial defoliation from the $0 \mathrm{~N}$ and $+\mathrm{N}$ plots in each block (plots not receiving defoliation treatments) by sampling a $20 \times 20 \mathrm{~cm}$ to a $25-\mathrm{cm}$ depth below ground surface. The post-treatment mass was measured immediately after the defoliation treatments by sampling to a $25-\mathrm{cm}$ depth using an iron tube $7 \mathrm{~cm}$ in diameter.

Samples were washed to remove soil and were then separated into stubble (stems, leaf sheaths, and aboveground dead materials), stolons, roots, and belowground dead materials (dead stolons and roots). Laminae were rarely sampled because of their complete removal by defoliation treatments. Dead stolons and roots were distinguished from live tissues, based on their degree of decay by appearance and touch (color, fragility, and solidity). Tissues under decay were separated and categorized as dead materials. The samples were oven-dried at $85^{\circ} \mathrm{C}$ for 72 hours for dry matter determination.

\section{Data analyses}

The effect of nitrogen treatments on the mass of the stubble-stolon-root system at the commencement of defoliation treatments was evaluated by a paired t-test. The effect of nitrogen $(0 \mathrm{~N}$ and $+\mathrm{N})$ and defoliation (D1, D2, and D4) treatments on tiller density, tiller survival, lamina production and mass of the stubble-stolonroot system was evaluated with ANOVA (block as an independent source of variation) and the means were compared with LSD.

The rate of decrease in tiller density of individual cohort with the progress of defoliation treatments was expressed by a decay constant (b, tillers tiller ${ }^{-1}$ day $^{-1}$ ), taking the decrease as an exponential change:

$$
\mathrm{N}=\mathrm{N}_{0} \exp (-\mathrm{bt})
$$

where $\mathrm{N}$ is the tiller density (tillers $\mathrm{m}^{-2}$ ), $\mathrm{N}_{0}$ is a constant (initial tillers $\mathrm{m}^{-2}$ ), and $\mathrm{t}$ is time (day). This equation was fitted separately for data from 2 stages of defoliation because tiller survivorship showed different patterns between these stages. Data after Week 9 were not included in the calculation for decay constants because zero survival (not logarithmically transformable) was common in some treatments. Lamina production rate was expressed as daily yield of laminae which was calculated every 4 days for comparison between D1, D2, and D4 treatments. Percentage or relative change $\left(\Delta \mathrm{M}_{\text {rel }}\right)$ in the mass of stubble, stolons, and roots during defoliation treatments was calculated as:

$$
\Delta \mathrm{M}_{\text {rel }}=100 \times\left(\mathrm{M}_{\text {post }}-\mathrm{M}_{\text {pre }}\right) / \mathrm{M}_{\text {pre }} \text { (2) }
$$
where $M_{\text {pre }}$ and $M_{\text {post }}$ are masses ( $g$ DM $\mathrm{m}^{-2}$ ) at the beginning and the end of the treatments, respectively. treatments (i.e., Weeks 1 to 4 and 5 to 9 )

\section{Results and Discussion}

\section{Sward characteristics at the beginning of defoliation treatments}

At the commencement of defoliation treatments (i.e., end of nitrogen treatments), total tiller densities were higher in $+\mathrm{N}$ than in $0 \mathrm{~N}$ (Table 1 and Fig. 2). Within each nitrogen level, total tiller densities did not differ among plots allotted to 3 defoliation regimes $(\mathrm{P}>0.05)$. In all treatments, original tillers (formed before the initial tagging in March 1998) and tillers initiated in the following 3 springs showed relatively high densities. In $+\mathrm{N}$ treatments, tillers initiated in the 3 summers also showed relatively high densities. Mass of stubble-stolon-root system was between 1,276 and 1,596 $\mathrm{g} \mathrm{DM} \mathrm{m}^{-2}$ (Fig. 3 ). Stolons accounted for 31 to $36 \%$ of total mass (395 to $570 \mathrm{~g} \mathrm{DM} \mathrm{m}^{-2}$ ) and belowground dead materials accounted for only 14 to $16 \%$ (204 to $225 \mathrm{~g} \mathrm{DM} \mathrm{m}^{-2}$ ). $+\mathrm{N}$ showed higher mass of stubble and stolons than $0 \mathrm{~N}$.

Thus, preceding nitrogen treatments produced swards with different characteristics at the commencement of defoliation treatments. The higher total tiller density and mass of stubble and stolons in $+\mathrm{N}$ than in $0 \mathrm{~N}$ agree with previous observations that an increase in nitrogen fertilizer rate increased tiller density (Pakiding and Hirata 2000) and stolon mass (Hirata 1994) in bahiagrass swards. The relatively high contributions of tillers initiated in spring $(0 \mathrm{~N}$ and $+\mathrm{N})$ and summer $(+\mathrm{N})$ to the total tiller population also agree with previous observations that tiller recruitment in bahiagrass is most active in mid- to late spring or early summer (Pakiding and Hirata 2000, Hirata and Pakiding 2001).

Table 1. Treatment means and ANOVA results (F-value) for tiller densities at the beginning and

\begin{tabular}{|c|c|c|c|c|}
\hline \multirow[t]{2}{*}{ Nitrogen rate } & \multirow{2}{*}{$\begin{array}{c}\text { Defoliation } \\
\text { frequency }\end{array}$} & \multicolumn{2}{|c|}{ Tiller density } & \multirow[t]{2}{*}{ Survival } \\
\hline & & Pre-treatment & Post-treatment & \\
\hline & (days) & - & 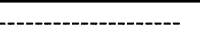 & $(\%)$ \\
\hline \multirow[t]{3}{*}{0} & 1 & 4,600 & 92 & 2.0 \\
\hline & 2 & 4,008 & 108 & 2.6 \\
\hline & 4 & 4,325 & 1,442 & 31.7 \\
\hline \multirow[t]{3}{*}{+} & 1 & 5,242 & 133 & 2.6 \\
\hline & 2 & 5,275 & 58 & 1.1 \\
\hline & 4 & 6,392 & 2,417 & 39.2 \\
\hline \multicolumn{5}{|c|}{ Source of variation $^{1}$} \\
\hline \multicolumn{2}{|c|}{ Nitrogen rate $(\mathrm{N})$} & $38.9 *$ & 1.9 & 0.2 \\
\hline \multicolumn{2}{|c|}{ Defoliation frequency (D) } & 3.9 & $26.7 * * *$ & $22.8 * * *$ \\
\hline \multicolumn{2}{|c|}{$\mathrm{N} \times \mathrm{D}$} & 3.8 & 1.9 & 0.3 \\
\hline \multicolumn{2}{|l|}{ Block } & $7.9 *$ & 0.3 & 0.3 \\
\hline \multicolumn{2}{|l|}{$\operatorname{LSD}(0.05)$} & 820 & 911 & 18.0 \\
\hline
\end{tabular}
the end of defoliation treatments and survival rate of tillers. 


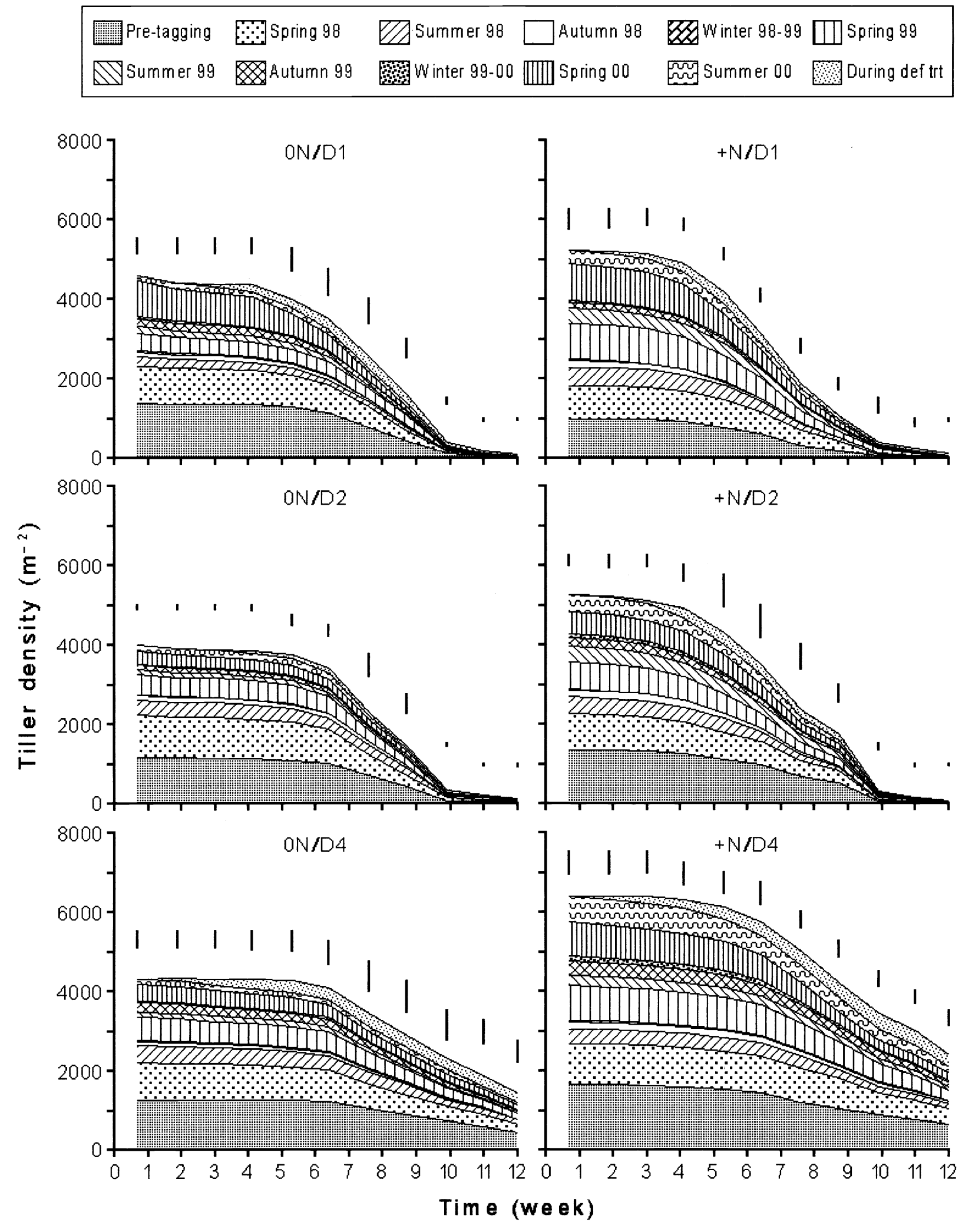

Fig. 2. Changes in density of tillers in different age cohorts after commencement of defoliation treatments over 8-day intervals. Tiller cohorts are stacked in an order of their age (the oldest cohort in the bottom and the youngest cohort on the top): pre-tagging, spring 1998, summer 1998, autumn 1998, winter 1998-1999, spring 1999, summer 1999, autumn 1999, winter 1999-2000, spring 2000, summer 2000, and during defoliation treatments. Vertical bars indicate SE of mean of total tiller density. 
Table 2. Decay constant of tiller density (tillers $(1,000 \text { tillers) })^{-1}$ day $^{-1}$ ) for individual tiller cohorts at 2 stages (Weeks 1 to 4 and 5 to 9) during defoliation treatments.

\begin{tabular}{|c|c|c|c|c|c|c|c|}
\hline Weeks & $\begin{array}{l}\text { Initiation time of tiller } \\
\text { cohorts }\end{array}$ & 0N/D1 & 0N/D2 & 0N/D4 & $+\mathrm{N} / \mathrm{D} 1$ & $+\mathrm{N} / \mathrm{D} 2$ & +N/D4 \\
\hline 1 to 4 & $\begin{array}{l}\text { Pre-tagging } \\
\text { Spring 1998 } \\
\text { Summer 1998 } \\
\text { Autumn 1998 } \\
\text { Winter 1998-1999 } \\
\text { Spring 1999 } \\
\text { Summer 1999 } \\
\text { Autumn 1999 } \\
\text { Winter 1999-2000 } \\
\text { Spring 2000 } \\
\text { Summer 2000 }\end{array}$ & $\begin{array}{c}0.9^{\mathrm{cd}} \\
3.4^{\mathrm{bcd}} \\
5.6^{\mathrm{bc}} \\
5.9^{\mathrm{bc}} \\
14.5^{\mathrm{a}} \\
7.1^{\mathrm{b}} \\
4.3^{\mathrm{bcd}} \\
1.7^{\mathrm{cd}} \\
0.0^{\mathrm{d}} \\
7.1^{\mathrm{b}} \\
0.0^{\mathrm{d}}\end{array}$ & $\begin{array}{r}1.5^{\mathrm{a}} \\
2.6^{\mathrm{a}} \\
2.0^{\mathrm{a}} \\
0.0^{\mathrm{a}} \\
0.0^{\mathrm{a}} \\
2.0^{\mathrm{a}} \\
10.2^{\mathrm{a}} \\
0.0^{\mathrm{a}} \\
0.0^{\mathrm{a}} \\
5.9^{\mathrm{a}} \\
0.0^{\mathrm{a}}\end{array}$ & $\begin{array}{l}0.3^{\mathrm{a}} \\
2.6^{\mathrm{a}} \\
1.8^{\mathrm{a}} \\
7.9^{\mathrm{a}} \\
0.0^{\mathrm{a}} \\
3.8^{\mathrm{a}} \\
3.0^{\mathrm{a}} \\
6.1^{\mathrm{a}} \\
0.0^{\mathrm{a}} \\
6.0^{\mathrm{a}} \\
2.4^{\mathrm{a}}\end{array}$ & $\begin{array}{r}2.6^{\mathrm{b}} \\
2.9^{\mathrm{b}} \\
5.8^{\mathrm{b}} \\
10.6^{\mathrm{b}} \\
31.5^{\mathrm{a}} \\
5.2^{\mathrm{b}} \\
4.1^{\mathrm{b}} \\
4.5^{\mathrm{b}} \\
6.8^{\mathrm{b}} \\
5.7^{\mathrm{b}} \\
3.7^{\mathrm{b}}\end{array}$ & $\begin{array}{r}3.0^{\mathrm{a}} \\
5.4^{\mathrm{a}} \\
5.0^{\mathrm{a}} \\
1.8^{\mathrm{a}} \\
-0.1^{\mathrm{a}} \\
7.6^{\mathrm{a}} \\
5.7^{\mathrm{a}} \\
3.5^{\mathrm{a}} \\
4.0^{\mathrm{a}} \\
2.6^{\mathrm{a}} \\
9.4^{\mathrm{a}}\end{array}$ & $\begin{array}{l}2.0^{\mathrm{a}} \\
1.4^{\mathrm{a}} \\
0.0^{\mathrm{a}} \\
3.6^{\mathrm{a}} \\
0.0^{\mathrm{a}} \\
1.9^{\mathrm{a}} \\
2.8^{\mathrm{a}} \\
5.2^{\mathrm{a}} \\
0.0^{\mathrm{a}} \\
3.6^{\mathrm{a}} \\
0.5^{\mathrm{a}}\end{array}$ \\
\hline 5 to 9 & $\begin{array}{l}\text { Pre-tagging } \\
\text { Spring 1998 } \\
\text { Summer } 1998 \\
\text { Autumn 1998 } \\
\text { Winter 1998-1999 } \\
\text { Spring 1999 } \\
\text { Summer 1999 } \\
\text { Autumn 1999 } \\
\text { Winter 1999-2000 } \\
\text { Spring 2000 } \\
\text { Summer 2000 }\end{array}$ & $\begin{array}{l}45.3^{\mathrm{bc}} \\
47.6^{\mathrm{abc}} \\
34.4^{\mathrm{bcde}} \\
38.7^{\mathrm{bcd}} \\
15.1^{\mathrm{e}} \\
16.4^{\mathrm{de}} \\
55.8^{\mathrm{ab}} \\
37.0^{\mathrm{bcde}} \\
15.1^{\mathrm{e}} \\
68.2^{\mathrm{a}} \\
30.8^{\text {cde }}\end{array}$ & $\begin{array}{l}38.3^{\mathrm{ab}} \\
53.1^{\mathrm{a}} \\
27.4^{\mathrm{ab}} \\
24.7^{\mathrm{ab}} \\
0.0^{\mathrm{b}} \\
42.0^{\mathrm{a}} \\
48.7^{\mathrm{a}} \\
52.6^{\mathrm{a}} \\
46.4^{\mathrm{a}} \\
45.0^{\mathrm{a}} \\
27.8^{\mathrm{ab}}\end{array}$ & $\begin{array}{l}14.4^{\mathrm{a}} \\
23.2^{\mathrm{a}} \\
14.9^{\mathrm{a}} \\
33.7^{\mathrm{a}} \\
51.8^{\mathrm{a}} \\
21.0^{\mathrm{a}} \\
39.8^{\mathrm{a}} \\
23.6^{\mathrm{a}} \\
14.6^{\mathrm{a}} \\
18.3^{\mathrm{a}} \\
2.6^{\mathrm{a}}\end{array}$ & $\begin{array}{c}62.8^{\mathrm{a}} \\
44.4^{\mathrm{a}} \\
63.3^{\mathrm{a}} \\
86.0^{\mathrm{a}} \\
2^{-} \\
58.8^{\mathrm{a}} \\
55.8^{\mathrm{a}} \\
61.5^{\mathrm{a}} \\
60.9^{\mathrm{a}} \\
62.1^{\mathrm{a}} \\
54.3^{\mathrm{a}}\end{array}$ & $\begin{array}{c}33.3^{\mathrm{a}} \\
36.9^{\mathrm{a}} \\
44.6^{\mathrm{a}} \\
57.7^{\mathrm{a}} \\
- \\
48.1^{\mathrm{a}} \\
27.3^{\mathrm{a}} \\
43.1^{\mathrm{a}} \\
50.6^{\mathrm{a}} \\
45.9^{\mathrm{a}} \\
46.9^{\mathrm{a}}\end{array}$ & $\begin{array}{r}16.5^{\mathrm{a}} \\
10.3^{\mathrm{a}} \\
15.6^{\mathrm{a}} \\
21.5^{\mathrm{a}} \\
0.0^{\mathrm{a}} \\
14.4^{\mathrm{a}} \\
21.1^{\mathrm{a}} \\
16.8^{\mathrm{a}} \\
25.3^{\mathrm{a}} \\
33.8^{\mathrm{a}} \\
19.8^{\mathrm{a}}\end{array}$ \\
\hline
\end{tabular}

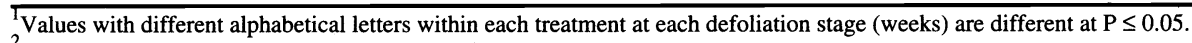

${ }^{2}$ Not calculated because data included zero survival.

\section{Sward dynamics during defoliation treatments}

After the commencement of defoliation treatments, tiller densities tended to remain constant for the first 4 to 6 weeks, but sharply declined thereafter (Fig. 2). Almost all tillers were dead after 12 weeks in D1 and D2. The final tiller densities and survival rates of tillers were ranked D1 $\approx$ D2 < D4, with no significant effect of nitrogen (Table 1). Some new tillers appeared during the defoliation treatment (i.e., the 12th cohort; Fig. 2). Tillers in the 11 age cohorts formed before the defoliation treatments showed similar survivorship and there were usually no significant differences in the decay constants among cohorts within each treatment at each defoliation stage (Table 2).

Lamina production started to decline immediately after the commencement of defoliation treatments and decreased to almost zero after 10 weeks (Fig. 4). Lamina production rate which was higher in +N/D4 than in other treatments throughout the treatment period $(\mathrm{P}<0.05)$ was also reflected in the total lamina production (Fig. 5).

By the end of the defoliation treatments, the mass of remaining stolons was as low as 0 to $95 \mathrm{~g} \mathrm{DM} \mathrm{m}^{-2}$ (0 to $6 \%$ of total mass) with a trend of $\mathrm{D} 1 \approx \mathrm{D} 2<\mathrm{D} 4$ (Fig. 6). Belowground dead materials, mainly dead stolons, were as high as 507 to 1,136 g DM m$~_{-2}$ (46 to $60 \%$ of total mass), showing a trend of greater masses in
$+\mathrm{N} / \mathrm{D} 1$ and $+\mathrm{N} / \mathrm{D} 2$ than other treatments. The mass of stubble and stolons was always reduced by defoliation, but root mass seemed almost unchanged with no consistent trend of increase or decrease (Fig. 7). The percentage loss in stolon mass was greater than that in stubble mass, with the loss tending to be D4 $<$ D1

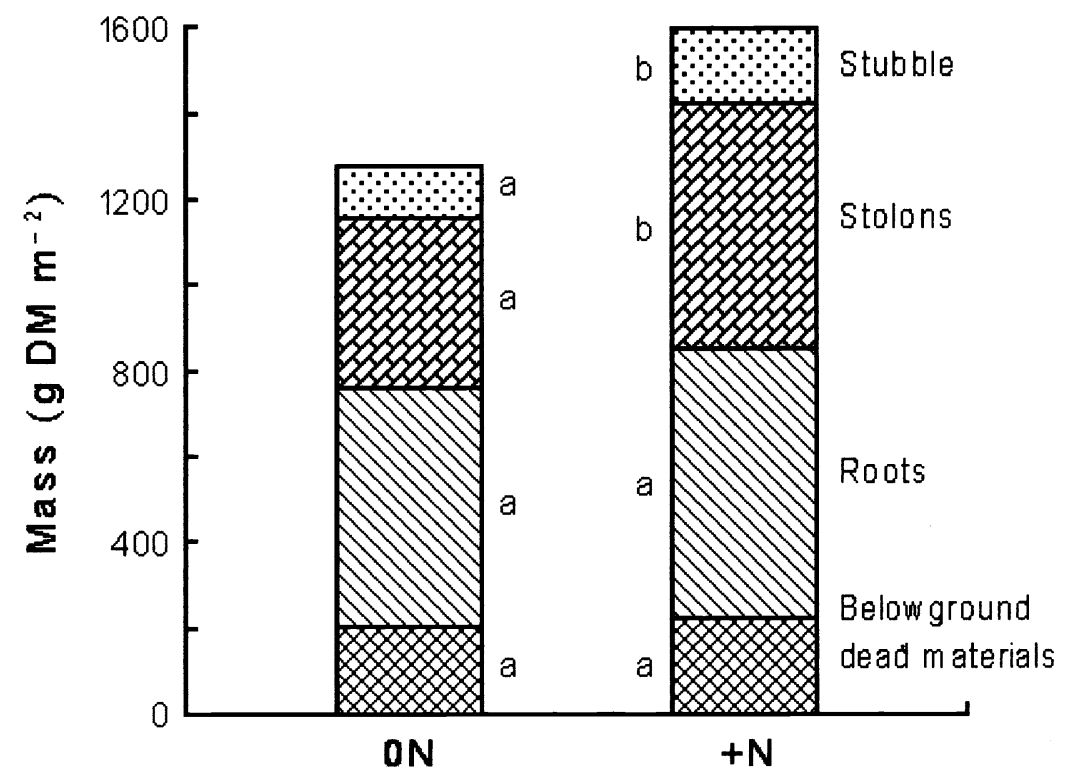

Fig. 3. Mass of stubble-stolon-root system at the start of defoliation treatments. System components are stubble (stems + leaf sheaths + aboveground dead materials), stolons, roots, and belowground dead materials, shown from the top to the bottom. Values with different letters within each component are significantly different at $\mathbf{P} \leq \mathbf{0 . 0 5}$. 
Thornton et al. 2000). Although the current study did not quantify reserves as carbon or nitrogen compounds, the largest biomass losses in stolons within the stubble-stolon-root system (Fig. 7) indicate that bahiagrass coped with the defoliation treatments at the cost of stolons. Thus, the results of this study confirm that stolons play a key role in defoliation tolerance in bahiagrass as the main storage organ supporting aboveground parts (Beaty et al. 1970). On the contrary, the almost unchanged root masses during defoliation treatments (Fig. 7) may reflect little contribution of reserves in root systems to defoliation tolerance in bahiagrass. It has been shown that carbohydrates allocated to root systems in perennial grasses are not capable of being remobilized for subsequent use in aboveground parts following defoliation (Briske 1991, Briske and Richards 1994), even when root mass is reduced by severe defoliation (Heady and Child 1994, Dawson et al. 2000).

The higher tiller survival in D4 than D1 and D2 (Table 1 and Fig. 2) can be largely explained by the fact that tillers in D4 were able to maintain laminae longer than D1 and D2, i.e., D4 tillers were less dependent on remobilized reserve substances. This explanation is supported by the tendency of smaller relative losses in stolon mass in D4 than in D1 and D2 (Fig. 7). In spite of the higher total tiller density and mass of stubble and stolons in $+\mathrm{N}$ than in $0 \mathrm{~N}$ at the commencement of defoliation treatments, tiller survival was not affected by nitrogen rate $(0 \mathrm{~N} \approx+\mathrm{N})$ (Table 1 and Fig. 2). A possible hypothesis for explaining this phenomenon is that $+\mathrm{N}$ tillers consumed more reserves in stolons for lamina production and depleted reserves to the same level as $0 \mathrm{~N}$ tillers, thus leading to the same degrees of tiller survival in $0 \mathrm{~N}$ and $+\mathrm{N}$. Hirata (2000) reported that rates of both leaf appearance and extension in bahiagrass increased with increased nitrogen rate. Our hypothesis is supported for D4, as +N/D4 produced more laminae than 0N/D4 (Figs. 4 and 5). However, the hypothesis is not supported for D1 and D2 because lamina production was not significantly influenced by nitrogen rate, though $+\mathrm{N}$ tended to show higher production than $0 \mathrm{~N}$. Further studies are necessary for fully understanding the mechanisms behind the absence of nitrogen effects on tiller survival in bahiagrass.

Zhang and Romo (1995) and McKenzie (1997), investigating impacts of defoliation on survival of tillers in different age cohorts in northern wheatgrass (Agropyron dasystachyum (Hook.)

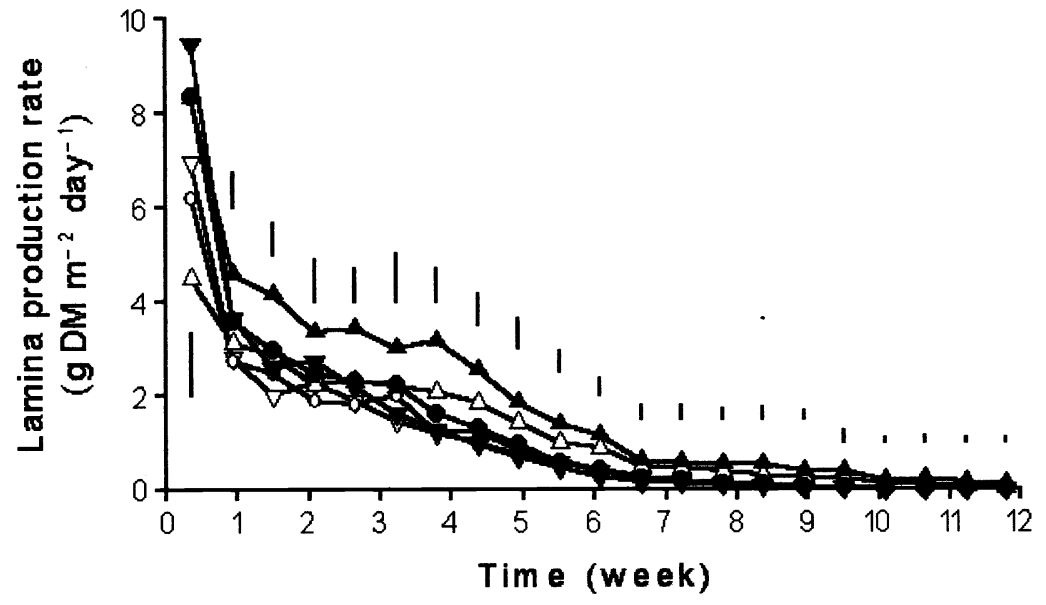

Fig. 4. Changes in lamina production rate after commencement of defoliation treatments. Nitrogen and defoliation treatments are 0N/D1 $(\nabla), 0 N / D 2(O), 0 N / D 4(\Delta),+N / D 1(\nabla)$, $+\mathrm{N} / \mathrm{D2}(\mathrm{O})$, and +N/D4 (A). Vertical bars indicate LSD $(\mathrm{P} \leq 0.05)$.
Scribn.) and perennial ryegrass (Lolium perenne L.), respectively, observed that the youngest tillers died first when the whole plant was stressed. They attributed the low defoliation-resistance of the youngest tillers to the fact that new tillers are entirely dependent on their parent tillers for energy and nutrient supplies and if parent tillers are defoliated, the resource is diverted for maintaining parent tillers (e.g., lamina elongation) rather than for supporting daughter tillers. However in the current study, the youngest tillers, i.e., produced in summer 2000 , did not die most quickly under severe defoliation, usually showing similar survivorship to other cohorts (Table 2). A possible explanation for this inconsistency may be that the youngest tillers of bahiagrass were able to utilize energy and nutrients in stolons without depending greatly on their parent tillers. Bahiagrass has a large mass of stolons (up to $1,200 \mathrm{~g} \mathrm{DM} \mathrm{m}^{-2}$; Beaty et al. 1970, Hirata and Ueno 1993, Hirata 1994) which act as the main storage organ supporting aboveground growth (Beaty et al. 1970, 1974, Hirata et al. 1990). In the current study, stolons also showed a high biomass of 395 to $570 \mathrm{~g} \mathrm{DM} \mathrm{m}^{-2}$ at the commencement of defoliation treatments (Fig. 3). We thus assume that all tillers shared energy and nutrients in connecting stolons under severe defoliation, though further detailed studies are needed for validating this hypothesis.

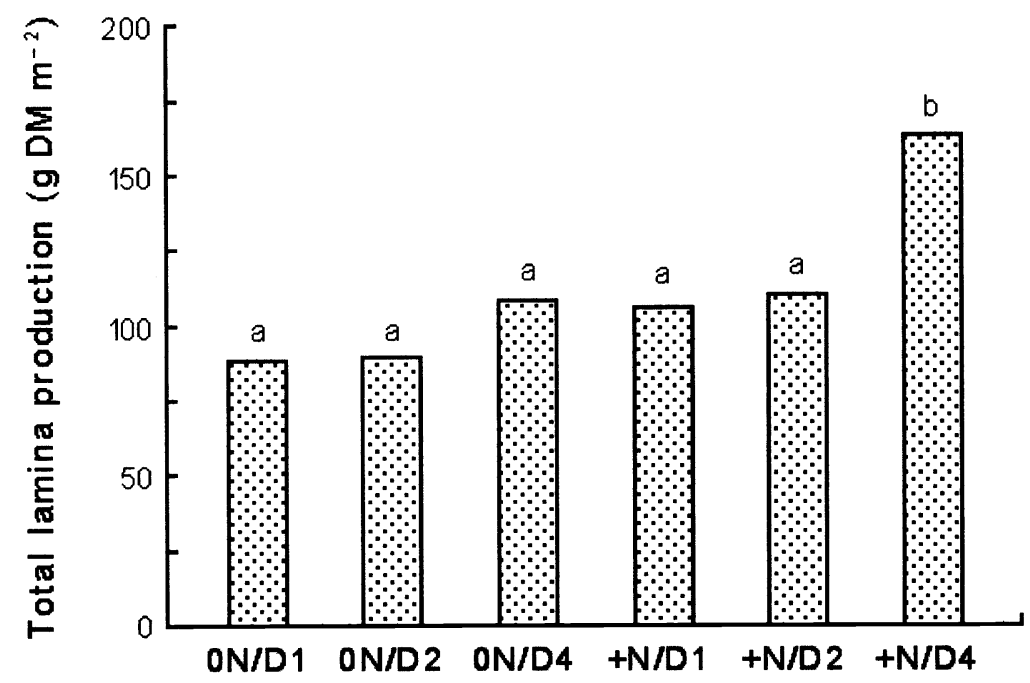

Fig. 5. Total lamina production during defoliation treatments. Values with different letters are significantly different at $P \leq \mathbf{0 . 0 5}$. 


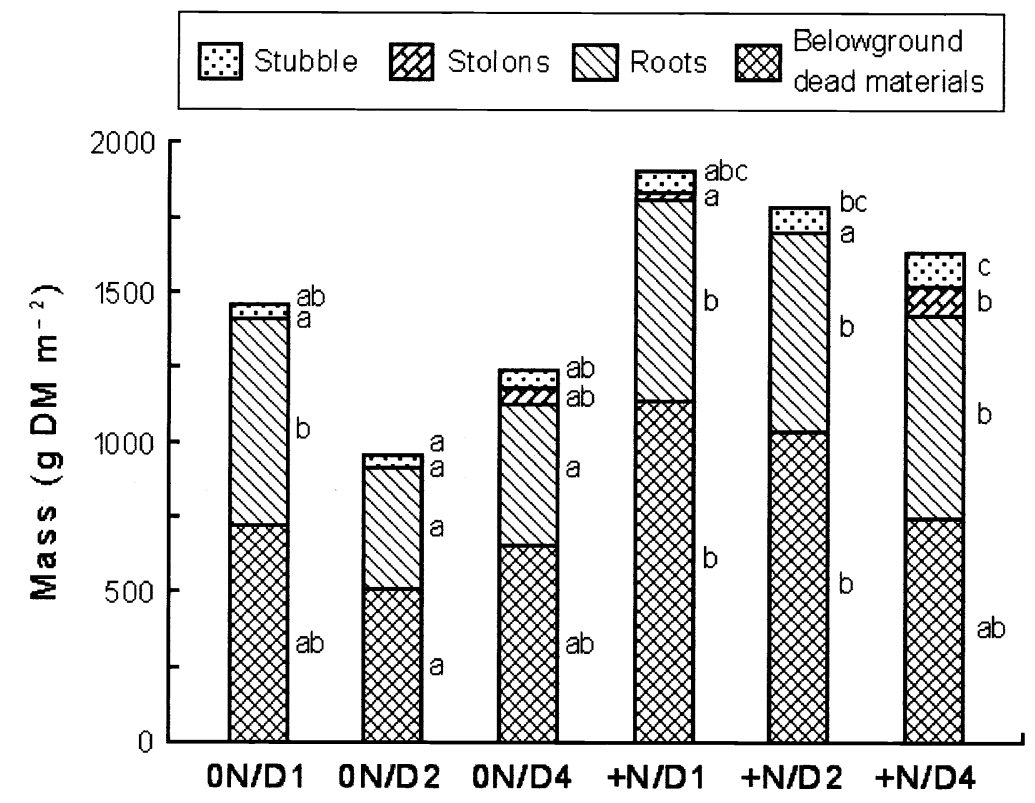

Fig. 6. Mass of stubble-stolon-root system at the end of defoliation treatments. System components are stubble (stems + leaf sheaths + aboveground dead materials), stolons, roots, and belowground dead materials, shown from the top to the bottom. Values with different letters within each component are significantly different at $\mathbf{P} \leq \mathbf{0 . 0 5}$.

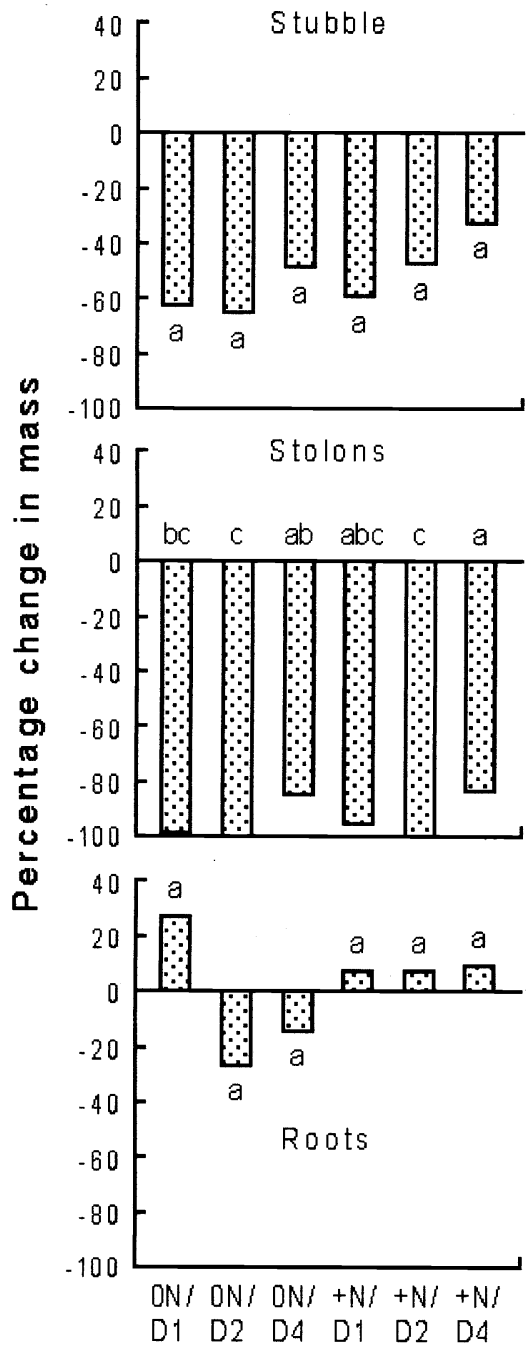

\section{Conclusions}

Removing all laminae every 1-4 days degrades bahiagrass swards, with tiller density, lamina production and mass of stubble and stolons being reduced. Survival of tillers and loss of stolon biomass are dependent on defoliation frequency but not on nitrogen fertilizer rate. Unlike some other grasses, survival ability of bahiagrass tillers does not differ among tiller age cohorts, suggesting that all tillers in bahiagrass are able to share energy and nutrients in connecting stolons under severe defoliation. Stolons play a key role in defoliation tolerance in bahiagrass as the main storage organ supporting aboveground parts, whereas the contribution of roots seems nil.

\section{Literature Cited}

Beaty, E.R., R.H. Brown, and J.B. Morris. 1970. Response of Pensacola bahiagrass to intense clipping, p. 538-542. In: Proc. $11^{\text {th }}$ Int. Grassl. Congress. Surfers Paradise, Australia.

Beaty, E.R., J.L. Engel, and J.D. Powell. 1977. Yield, leaf growth, and tillering in bahiagrass by $\mathrm{N}$ rate and season. Agron. J. 69:308-311.

Beaty, E.R., E.V.S.B. Sampaio, D.A. Ashley, and R.H. Brown. 1974. Partitioning and translocation of ${ }^{14} \mathrm{C}$ photosynthate by bahiagrass (Paspalum notatum, Flugge), p. 259-266. In: Proc. $12^{\text {th }}$ Int. Grassl. Congress. Moscow, USSR.

Briske, D.D. 1991. Developmental morphology and physiology of grasses, p. 85-108. In: R.K. Heitschmidt and J.W. Stuth (eds.), Grazing management: an ecological perspective. Timber Press, Portland, Oreg.

Briske, D.D. and J.H. Richards. 1994. Physiological responses of individual plants to grazing: current status and ecological significance, p. 147-176. In: M. Vavra, W.A. Laycock, and R.D. Pieper (eds.) Ecological implications of livestock herbivory in the West. Soc. for Range Manage., Denver, Colo.

Dawson, L.A., S.J. Grayston, and E. Paterson. 2000. Effects of grazing on the roots and rhizosphere of grasses, p. 61-84. In: G. Lemaire, J. Hodgson, A. de Moraes, P.C. de F. Carvalho, and C. Nabinger (eds.), Grassland ecophysiology and grazing ecology. CABI Publ., Wallingford, UK.

Fig. 7. Percentage changes in the mass of stubble (stems + leaf sheaths + aboveground dead materials), stolons and roots during defoliation treatments. Values with different letters within each component are significantly different at $P \leq \mathbf{0 . 0 5}$.
Heady, H.F. and R.D. Child. 1994. Rangeland ecology and management. Westview Press, Boulder, Colo.

Hirata, M. 1993a. Response of bahiagrass (Paspalum notatum Flügge) sward to cutting height. 2. Yield and in vitro digestibility of herbage. J. Japan. Grassl. Sci. 39:183-195. 
Hirata, M. 1993b. Response of bahiagrass (Paspalum notatum Flügge) sward to cutting height. 3. Density of tillers, stolons and primary roots. J. Japan. Grassl. Sci. 39:196-205.

Hirata, M. 1994. Response of bahiagrass (Paspalum notatum Flügge) sward to nitrogen fertilization rate and cutting interval. 1. Dry weight of plant and litter. J. Japan. Grassl. Sci. 40:313-324.

Hirata, M. 2000. Effects of nitrogen fertiliser rate and cutting height on leaf appearance and extension in bahia grass (Paspalum notatum) swards. Trop. Grassl. 34:7-13.

Hirata, M. and W. Pakiding. 2001. Tiller dynamics in a bahia grass (Paspalum notatum) pasture under cattle grazing. Trop. Grassl. 35:151-160.

Hirata, M. and M. Ueno. 1993. Response of bahiagrass (Paspalum notatum Flügge) sward to cutting height. 1. Dry weight of plant and litter. J. Japan. Grassl. Sci. 38:487-497.
Hirata, M., Y. Sugimoto, and M. Ueno. 1990. Productivity and energy efficiency of bahiagrass (Paspalum notatum Flügge) pasture. III. Rate of increase in energy mass of plant parts. Bull. Fac. Agr., Miyazaki Univ. 36:383-390.

McKenzie, F.R. 1997. Influence of grazing frequency and intensity on the density and persistence of Lolium perenne tillers under subtropical conditions. Trop. Grassl. 31:219-226.

Pakiding, W. and M. Hirata. 2000. Effects of nitrogen fertilization rate and cutting height on tiller dynamics in bahiagrass (Paspalum notatum Flügge) swards. Grassl. Sci. 46(ext.):40-41.

Pakiding, W. and M. Hirata. 2001. Leaf appearance, death and detachment in a bahia grass (Paspalum notatum) pasture under cattle grazing. Trop. Grassl. 35:114-123.
Skerman, P.J. and F. Riveros. 1989. Tropical grasses. FAO, Rome.

Stanley, R.L., E.R. Beaty, and J.D. Powell. 1977. Forage yield and percent cell wall constituents of Pensacola bahiagrass as related to $\mathrm{N}$ fertilization and clipping height. Agron. J. 69:501-504.

Thornton, B., P. Millard, and U. Bausenwein. 2000. Reserve formation and recycling of carbon and nitrogen during regrowth of defoliated plants, p. 85-99. In: G. Lemaire, J. Hodgson, A. de Moraes, P.C. de F. Carvalho, and C. Nabinger (eds.) Grassland ecophysiology and grazing ecology. CABI Publ., Wallingford, UK.

Zhang, J. and J.T. Romo. 1995. Impacts of defoliation on tiller production and survival in northern wheatgrass. J. Range Manage. $48: 115-120$ 